\title{
The Admissibility of Criminal Convictions in Subsequent Civil Proceedings
}

\section{Zelman Cowen*}

\begin{abstract}
Rule 521 of the Model Code of Evidence provides that
Evidence of a subsisting judgment adjudging a person guilty of a crime or a misdemeanour is admissible as tending to prove the facts recited therein and every fact essential to sustam the judgment.
\end{abstract}

The comment on the rule expressly acknowledges that it goes further than the decisions, and notes that practice in various jurisdictions is diverse. In some cases, the matter has been dealt with by legislation. An example is Section 5 of the Clayton Act which provides that any final judgment in any criminal prosecution brought by or on behalf of the United States in respect of breaches of anti-trust legislation, holding that the defendant has violated those laws, shall be prima facie evidence against such defendant in any suit brought by any other person against him as to all matters respecting which the original judgment would constitute an estoppel as between the parties thereto. ${ }^{1}$

Apart from the cases where legislation has affected the issue, the decisions range from admissibility with conclusive effect to total inadmissibility. In Eagle Star and British Dominions Insurance Co. v. Heller ${ }^{2}$ it was held in the case of a person convicted of burning the insured property that the conviction was conclusive proof in an action brought on the policy. The court said that to hold otherwise would "discredit the administration of justice, defy public policy and shock the most unenlightened conscience .... [It] would be to encourage and give support to the current thoughtlessness and carping criticisni of legal procedure and to justify the jibe that the administration of the law is the only remaining legalized lottery." The court emphasized that what was said applied only to such cases as were before it and that no opinion was expressed as to the case of a tort action following a criminal conviction for personal injury. In Schindler v. Royal Insurance $\mathrm{Co}^{3}$ there was a claim under an insurance policy which contained a clause avoiding liability on the policy in the event of fraud on the part of the insured touching the subject matter of the insurance. The insured had been convicted of making a fraudulent claini in respect of the policy. It was held by the New York Court of Appeals that the conviction was admissible as prima facie evidence in the subsequent civil proceedings. It is interesting to note that the court discussed a number of English authorities.

* Dean of the Law School and Professor of Public Law, University of Melbourne, Australia.

1 See Emich Motors Corp. v. General Motors Corp., 340 U.S. 558 (1951).

2149 Va. 82, 140 S.E. 314 (1927).

3258 N.Y. 310,179 N.E. 711 (1932). 
A similar result was reached by a Colorado court in North River Insurance Co. of N.Y.v. Millitello ${ }^{4}$ on similar facts, where it was said of the conviction that "it is such presumptive proof as to shift the burden to him to establish his innocence thereof." In Matter of Rechtschaffen, $X$ applied for letters of administration to the estate of the deceased. $Y$, the spouse of the deceased, cross-petitioned. To prevent the grant to $Y, X$ sought and was permitted to tender the record of a domestic relations court adjudging $Y$ a disorderly person for having deserted his spouse. This also was a decision of the New York Court of Appeals.

On the other side there are decisions against admissibility. In Girard v. Vermont Mutual Fire Insurance $\mathrm{Co}^{6}$ there was a claim on an insurance policy and the court refused to admit a conviction of the insured for arson. The court based the decision on the maxim res inter alios acta alteri nocere non debet, and held that the guilt of the insured must be proved de novo. In Interstate Dry Goods Stores v. Williamson, ${ }^{7}$ in holding against admissibility, a West Virginia court stressed the fact that the parties to the criminal and civil proceedings were different, as were the rules of evidence and purposes in the two jurisdictions.

Even within the jurisdictions of a single state of the United States there have been sharp differences on this question. This is illustrated by a recent examination of the trends of opinion in the inferior New York courts. ${ }^{8}$ In Walther v. News Syndicate Co., ${ }^{9}$ the plaintiff in a negligence action sought to put in evidence the defendant's conviction for dangerous driving. The First Department held the evidence inadmissible. The authority of Schindler v. Royal Insurance Co. was held limited to cases where the conviction was tendered defensively, i.e. as a defense to civil action, but not, as here, where the plaintiff sought to use it affirmatively in support of his claim. It was suggested that this distinction might not apply if the conviction had been in respect of a true crime as opposed to a mere traffic infraction. ${ }^{10}$ However, the Second Department, in Giessler v. Accurate Brass Co. Inc. ${ }^{11}$ held that the Schindler doctrime applied affirmatively. There it was held that a plaintiff might tender the defendant's previous criminal conviction in support of his suit for an injunction to restrain the defendant from maintaining a nuisance. In the Fourth Department, dicta in Same v. Davison ${ }^{12}$ support the affirmative use of the prior conviction.

It will be seen fron these cases that while the New York courts adhere to a rule of admissibility, there is a division of opinion, not yet resolved by

\footnotetext{
4100 Colo. 343, 67 P. 2d 625 (1937).

5 278 N.Y. 336, 16 N.E. 2d 357 (1937).

6103 Vt. 330, 154 Atl. 666 (1931).

791 W. Va. 156, 112 S.E. 301 (1922).

8 See 2 Syracuse L. Rev. 106 (1950); 50 Cor. L. Rev. 529 (1950); 35 Coraele L. Q. 872

9276 App. Div. 169, 93 N.Y.S. 2d 537 (1949).

10 The decision has been criticized on the former ground, but justified on the latter. Sec 25 N.Y.U.L.Q. REv. 1273-4 (1950), but see 2 SYRACUSE L. REv. 106 (1950).

11271 App. Div. 980, 68 N.Y.S. 2d 1 (1947).

12253 App. Div. 123, 1 N.X.S. 2d 374 (1937).
} (1950). 
the New York Court of Appeals, as to whether it is possible to tender a conviction affirmatively, i.e. by a plaintiff in support of a civil claim. On principle it is submitted that the distinction between affirmative and defensive use of a conviction is highly dubious, when the real question concerns the probative value of the conviction. The answer to this question cannot vary according to the use to which the conviction is put.

This brief review of the authorities, which is not, of course, intended to be exhaustive, reflects a wide diversity of judicial opinion on this matter. The judicial differences are reflected also in the books. Wigmore, after drawing attention to the many provisions for admission $m$ evidence of various official inquisitions, reports, certificates and investigations in the course of duty, observes that in many situations it is "unreasonable and impractical to ignore the evidential use of a judgment in another proceeding involving the same fact as in the present case." 13 Wigmore's view ranges him -although perhaps not quite so certainly-with the supporters of the Model Code rule. Hinton, on the other hand, regarded the objections to admissibility as very serious. ${ }^{14}$ In his view the principal obstacles to admissibility were the hearsay and opinion rules. These objections were considered by Wigmore and brusquely dismissed. ${ }^{15}$

In view of the judicial and doctrinal differences on this point in the United States, a study of the treatment of the question in other common law jurisdictions is both relevant and instructive. Accordingly it is proposed to examine first the English decisions, and then the law in the various common law jurisdictions of the British Commonwealth.

\section{II}

At the outset, it must be noted that there is a comparatively recent unanimous decision of the English Court of Appeal, Hollington v. F. Hewthorn $\&$ Co., ${ }^{16}$ which in terms holds that criminal convictions are not admissible in subsequent civil proceedings to prove the facts on which the convictions are based. In the course of its opinion, the court, speaking through Lord Justice Goddard, observed that this rule might not commend itself to lay understanding.

No doubt, it is difficult for a layman to understand why it is that if $A$ prosecutes $B$, say, for doing him grievous bodily harm, and subsequently brings an action against him for dainages for assault, this doctrine should apply so that he cannot use the conviction as proof that $B$ did assault him. ${ }^{17}$

It is clear that this difficulty has not been experienced by laymen alone, as is evidenced by the views in favour of admissibility expressed by many courts and writers. ${ }^{18}$ However, in Hollington v. Hewthorn, the court pur-

135 WIGMORE, EvIDENCE 688 (3d ed. 1940).

14 Hinton, Judgment of Conviction; Effect on a Civil Case, 27 ILL. L. REv. 195 (1932).

155 WIGMORE 689.

16 [1943] K.B. 587. The court comprised three judges, Lord Greene, Master of the Rolls and Lords Justices Goddard and du Parcq.

1r Id. at 596.

18 Pripson, Evmence 407 (8th ed. 1942) says of the rule of exclusion that it "certainly savours of technicality." 
ported to rely both on authority and on principle. In considering the English law it is desirable, in the first place, that the course of authority should be reviewed.

The first group of cases to be considered were decided before 1843. The Evidence Act of that year removed many of the earlier disqualifications of witnesses on the ground of interest. This was an important Act, for a number of these earlier cases raise as an objection to admissibility the fact that the criminal conviction might have been obtained on the testimony of a person interested in the subsequent civil proceedings. To have admitted such evidence would have indirectly violated the interest-disqualification rule.

There is a decision of Holt C. J. in $R$. v. Warden of the Fleet ${ }^{10}$ against admissibility: "Conviction at the suit of the King for battery etc. cannot be given in evidence in an action of trespass for the same battery or vice versa." No reasons appear. In Hillyard v. Grantham, ${ }^{20}$ referred to by Lord Hardwicke in Brownsword v. Edwards, ${ }^{21}$ it appears that proceedings had been taken in an ecclesiastical court against a man and woman for living in fornication and sentence was pronounced. In subsequent legitimacy proceedings evidence of this conviction was held inadmissible to prove that the man and woman were not married. The reason given was that the conviction was res inter alios acta. In Gibson v. McCarty, ${ }^{22}$ a criminal conviction was again held inadmissible in subsequent civil proceedings. Lord Hardwicke referred to Hillyard v. Grantham, and also approved the argument of counsel that the conviction was inadmissible as it might have been obtained on the evidence of a party interested in the civil action. In Green $v$. New River $\mathrm{Co}^{23}$ there is support for the rule of exclusion, although, again, the reasons are not clear. In Smith $v$. Rummens, ${ }^{24}$ Lord Ellenborough held that if $A$ were convicted before a magistrate on the evidence of $B, B$ could not tender the conviction in any civil proceeding between him and $A$. "To admit it for the purpose proposed would be to allow him to swear in his own cause." Here the reason for exclusion is clearly interest. $R$. $v$. Whiting, ${ }^{25}$ which is also against admission, obiter, suggests the interest reason. Wilkinson v. Gordon ${ }^{26}$ is out of line. The question was whether a conviction for bigamy was admissible to prove the invalidity of a marriage. Sir John Nicholl in the Prerogative Court held that it was admissible. "I apprehend the true rule to be that a record of conviction is evidence of the same fact in a civil cause." There, argumens of res inter alios acta and interest had been raised against admissibility. The learned judge cited both Buller's Nisi Prius ${ }^{2 \pi}$ and Gilbert on Evidence ${ }^{28}$ in support of admissibility. How-

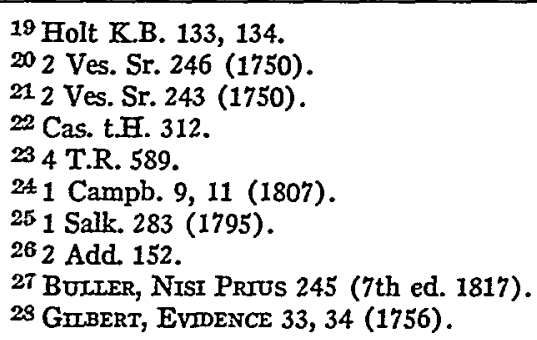


ever, this was not a decision of a common law court, and subsequently in Blakemore v. Glamorganshire Canal Co., ${ }^{29}$ Parke B. stated in general terms that such evidence was inadmissible. The question did not arise directly in that case so that the remarks of the judge were strictly obiter. Nevertheless it is a definite expression of opinion by a distinguished judge, and it is clear that Parke did not regard the interest disqualification as the sole basis of the rule which in his view rested upon the wider rule of res inter alios acta.

Apart from Wilkinson v. Gordon, which was not a decision of a common law court, and which in any event is in conflict with March v. March, ${ }^{30}$ where Sir Cresswell Cresswell held that a conviction for bigamy did not suffice to prove the bigamy in a subsequent divorce petition, the cases up to the date of the Evidence Act 1843 generally deny the admissibility of the criminal conviction. In $R e$ Crippen, ${ }^{31}$ Sir Samuel Evans P., who held that a conviction for murder was admissible in subsequent probate proceedings as proof of the fact that Crippen had murdered his wife, referred to pre-1843 authorities as having been decided on "narrow and special grounds" of interest disqualification which had disappeared with the legislation of 1843 and subsequent acts. Counsel in Hollington v. Hewthorn placed a similar interpretation on the cases. ${ }^{32}$ But as was pointed out by Hall V. C. in Yates $v . K y$ fin-Taylor ${ }^{33}$ and by Goddard L. J. in Hollington $v$. Hewthorn, ${ }^{34}$ this was not the sole reason for exclusion in these early cases. This is clear from the judgment of Parke B. in Blakemore v. Glamorganshire Canal $C o$., where he stated the basis of exclusion as res inter alios acta. Why the primciple of res inter alios acta should exclude the evidence is a question to which the answer is nowhere made clear in these cases. However, this reason has been constantly repeated in the more modern authorities and consideration of the question will be postponed to a later stage.

The authorities subsequent to 1843 now fall to be considered. March $v$. March, ${ }^{35}$ already referred to, is an authority against admissibility, but no reasons were given. There follow two cases, both of which have been heavily relied upon in subsequent decisions and by text writers, and which are strongly against admissibility. In the first of these, Castrique v. Imrie, Blackburn J., delivering the joint opinion of himself, Bramwell and Cleasby BB., Mellor and Brett JJ. said:

A judgment in an English Court is not conclusive as to anything but the point decided, and therefore a judgment on an indictment for forging a bill of exchange, though conclusive as to the prisoner being a convicted felon, is not only not conclusive, but is not even admissible evidence of the forgery

292 C.M. \& R. 133 (1835).

3028 T.J. (P. \& M.) 30 (1858).

31 [1911] P. 108, 113.

32 [1943] K.B. $587,589$.

33 [1899] W.N. 141.

34 [1943] K.B. 587, 597 et seq.

35 28 L.J. (P. \& M.) 30 (1858). Per Sir Cresswell: "You must remember that bigamy must be proved. Proof of the conviction of bigamy will not suffice."

36 L.R. 4 H.L. 414, 434 (1870). 
in an action on the bill, though the conviction must have proceeded on the ground that the bill was forged.

From such a distinguished judicial source, such a statement is entitled to the greatest respect. But the dictum is wholly obiter as the case involved an entirely different point, and is not supported by any reasons. A few years later in Leyman v. Latimer, ${ }^{37}$ Bramwell L. J. reiterated this view. In this case an action for libel was brought by a newspaper editor against whom it had been alleged that he was a "convicted felon" and a "felon editor." Bramwell L. J. held that the words "felon editor" implied that the person was actually guilty of a felony, and that a justification which did not allege the actual commission of a felony was too wide. The learned Lord Justice said:

It is plain from the numerous authorities cited in ... Taylor on Evidence ... that a conviction for felony is res inter alios acta, and of itself is no evidence in any civil proceeding that the person convicted has committed a felony.

In another report ${ }^{38}$ of this case Bramwell L.J. is reported as saying:

The conviction is no proof of the crime. It is res inter alios acta ... . The cases are rare, I am happy to say, in which there has been a wrongful conviction, but such cases have been, and the convicted person has been pardoned. It is right, therefore, where you charge a man, not with having been convicted of felony, but with having been a felon, that you should prove the charge which you actually make.

With regard to the first of these two passages, Sir Samuel Evans P. in

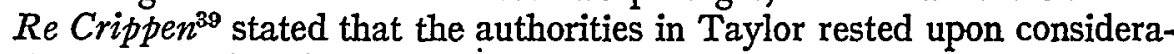
tions not applicable after the Evidence Act 1843. Examination of these authorities shows that this was not the sole reason for exclusion. But the second passage is worthy of note, because, apparently for the first time, reasons were given to show why the conviction should be treated as res inter alios acta.

Castrique v. Imrie and Leyman v. Latimer were followed by Hall V. C. in a careful judgment in the Court of Chancery of the County Palatine of Lancaster in Yates v. Kyffin-Taylor. ${ }^{40} Y$ left property to $W$ who was convicted of the murder of $Y$. Y's next-of-kin brought an action for a declaration that $W$ by reason of his felonious act had forfeited all his rights under the will. It was argued that the conviction was conclusive proof of the commission of the felony. Counsel contended that it 'would bring the administration of justice into disrepute if a criminal conviction against which there was no appeal could be reversed "on a side issue" after a review of the authorities, held that evidence of the conviction was

373 Ex. Div. 352, 354 (1878).

3847 L.J. (Q.B.) $470,471$.

39 [1911] P. 108, 113.

40 [1899] W.N. 141.

41 Id. at 143. 
not even admissible for this purpose. "The foundation of the doctrine ... is ... that matter which is res inter alios acta is not admissible in an action of this kind." 42

Hill v. Clifford ${ }^{43}$ is an important, though apparently forgotten, decision of the Court of Appeal. It is very odd that it was disregarded by Evans $P$. in support of his decision in Re Crippen and it hardly accords with the statement of Goddard L. J. in Hollington v. Herethorn" that "it has been the invariable practice of the judges for many years, certainly for so long as any nember of the court has been in the profession, to reject this class of evidence." In Hill v. Clifford the facts were that the General Medical Council, acting under the powers conferred upon it by the Dentists Act 1878 , made an order directing the registrar to strike the names of the Cliffords off the dental register on the ground that they had been guilty of conduct which was infamous or disgraceful in a professional respect. The Cliffords and the plaintiff had entered into articles of partnership which provided that a partner was at liberty to give written notice determining the partnership if a partner had been guilty of professional misconduct. Actions were brought to determine the validity of the notices terminating the partnership and a question was raised as to the admissibility of the order of the General Medical Council as evidence of professional misconduct. In the lower court ${ }^{45}$ it was argued that the evidence of the finding of the General Medical Council was inadmissible as res inter alios acta, citing Leyman v. Latimer. Warrington J. upheld this submission, but his judgment on this point was reversed by the Court of Appeal. There counsel made specific reference to Castrique v. Imrie, Leyman v. Latimer and Yates v. Kyffin-Taylor. Cozens-Hardy M.R. stated that the finding of the General Medical Council should be regarded as on the same footing as an inquisition and sufficed to prove the misconduct unless and until evidence established the contrary. Buckley L. J. expressed a similar opinion. Sir Gorell Barnes P. dealt inore hesitantly with the point. The learned President stated that he had been unable to satisfy himself that the Council's order could be tendered as evidence of the truth of the facts found, especially in view of the fact that it was based on evidence not given under oath. But having regard to the nature of the powers conferred on the Council and the position of the parties in their profession, the order might possibly be evidence that on the facts before them the Council found the defendants guilty of infamous conduct, and though the ordinary courts might be competent to consider whether the facts were true, it was extremely doubtful whether it was competent for these courts to hold that the Council had formed an erroneous opimion as to the nature of the conduct of the defendants. If it were possible to show that the opinion was erroneous "the remarkable position would be reached that the tribunal which is constituted

\footnotetext{
42 Id. at 145.

43 [1907] 2 Ch. 236.

44 [1943] K.B. 587, 593.

45 [1907] 1 Ch. 420, sub. nom. Chifford v. Timms.
} 
to deal with cases of professional misconduct, and to erase names for such conduct, and from whose decision there is no appeal, might be considered to have arrived at an erroneous conclusion by another tribunal which had not the same capacity of judging of what was professional misconduct as the former, and would require to be assisted by evidence of witnesses unless the finding of the Council is to be treated as the best evidence of what amounts to professional misconduct." ${ }^{46}$ In the House of Lords the case was decided on another point, and the question under consideration was not discussed. ${ }^{47}$

From this case it will be seen that two members of the court were clearly of opinion that the order of the General Medical Council was admissible in subsequent civil proceedings as evidence of the truth of the matters found. The opinion of Barnes $\mathrm{P}$. is rather difficult, for in curiously hesitant and obscure phrases he appears within a short space to move away from a position of inadmissibility to one in favour of admitting such evidence. It should be emphasized that the finding of the Council was not subject to the same evidentiary and procedural safeguards as a finding of guilt by a criminal court. If the Council's decision was admissible, the argument in favour of admitting a criminal conviction is, it is submitted, much stronger, because the safeguards surrounding accused persons in a criminal court are much greater than those which a domestic tribunal is obliged to provide for the protection of persons charged before it. The argument of Bramwell L. J. in Leyman v. Latimer is peculiarly relevant here. The findings of the Council, based as they might be on less stringent rules than obtain in a criminal court, might be wrong. It seems then that it is even more appropriate in such a case to say with Bramwell L. J. that "it is right, where you charge a inan, not with having been convicted ... but with having been [guilty of professional misconduct] . . . that you should prove the charge which you actually make."

This is not to suggest that Hill v. Clifford is an unsound decision. The submission is that it is a plain authority of the Court of Appeal opposed to the earlier decisions on the admissibility of criminal convictions in civil proceedings. It cannot be argued that the decision was reached per incuriam. The earlier authorities were fully canvassed in argument; in fact, they persuaded the learned judge below. It accordingly seems that Hill v. Clifford is a considered decision in favour of admissibility.

It is odd that the case was not referred to by Evans P. in Re Crippen, ${ }^{48}$ and does not appear to have been brought to his notice by counsel. In that case there was a motion for a grant of letters of administration to the estate of Mrs. Crippen and it was argued that the executrix of Dr. Crippen, who had been convicted and executed for the murder of his wife, should be passed over. Since Crippen was not entitled to participate in any benefits accruing froin the estate, an executrix appointed under his will was not

46 [1907] 2 Ch. 236, 253.

47 [1908] A.C. 12.

48 [1911] P. 108; 104 L.T. Probate 224 (1911). 
entitled to letters of administration of the estate of Mrs. Crippen. The question arose as to the admissibility of a certified copy of the conviction of Crippen as evidence in these proceedings that he had in fact murdered his wife. The President referred to the discretion vested in him by the Court of Probate Act 1857 to pass over a person nornally entitled to letters of administration by reason of the existence of special circumstances. Such special circumstances existed in the case of a man convicted of murder, and the discretion was exercised on this ground. In Hollington v. Hewthorn, Goddard L.J. treated the case as "beyond criticism" 49 on this ground. But it has been poimted out, with great reason, that there is some difficulty in explaining the case in this way, as the conviction would surely be an immaterial fact unless it served to prove that Crippen had murdered his wife..$^{50}$

Evans P., however, proceeded to consider the argument that the conviction was not admissible to prove the cominission of the murder by Crippen. Reference has already been made to the President's discussion of the pre-1843 authorities which he interpreted as resting upon the interest disqualification. Castrique v. Imrie and Leyman v. Latimer he declined to follow on the ground that what was said there was dictum, and Yates $v$. Kyffin-Taylor on the ground that it was not binding on him. Evans P. then stated his view in favour of admissibility. ${ }^{51}$

Is the fact of his conviction not evidence against him? Is it right to treat it as res inter alios acta and to say it is not admissible at all in a civil action brought by him? The complete maxim is Res inter alios acta alteri nocere non debet. There is no question of alteri nocere here .... I think the maxim ominia praesumuntur rite esse acta ought to apply .... It does not mean that the evidence need be, or is, conclusive. If it be that the rules of evidence ever were, or are, as contended for the executrix in this regard, I think in the circumstances attending trials for crimes in these days that they ought to be reconsidered and revised.

There are two points here which call for comment. It appears that the President thought that the maxim res inter alios acta alteri nocere non debet had only a limited application in these cases. It did not apply when the person adversely affected by the admission of the conviction was not "alterum." In this case Crippen's privy who stood in the same position as Crippen was a party both to the criminal and the civil proceedings. Evans P., however, thought that there might be cases in which this maxim might operate to exclude the evidence. Thus he suggested ${ }^{52}$ that the principle stated by Blackburn J. in Castrique v. Imrie might apply in a case where $A$ sued $B$ on a bill of exchange, and evidence was tendered of $C$ 's conviction for forgery of the bill. The decision has been criticized on this point. ${ }^{53}$ The point of the criticism is that the maxim res inter alios acta has its roots

\footnotetext{
49 [1943] K.B. 587, 600 .

50 Goodhart, 59 L.Q.R. 300 (1943).

51104 L.T. Probate 224, 226 (1911).

62 [1911] P. 108, 113-4.

53 Goodhart, 42 L.Q.R. 144 (1926).
} 
in the law of estoppel which is not relevant to the present question. All that it is sought to do in such cases as these is to tender the finding of a criminal court as prima facie evidence of its truth. If any Latin maxim is applicable in these circumstances it is the other one referred to by the learned President-omnia praesumuntur rite esse acta. This would lead to the conclusion that whether or not the conviction affected "alterum," it would still be admissible on a wider and more appropriate principle.

In a note by the President to his judgment in $R e$ Crippen, ${ }^{54}$ Evans $P$. referred to The Prince of Wales etc. Association Co. v. Palmer. ${ }^{55}$ That was a case involving a claim to an insurance policy and the question was whether the finding of a coroner's jury that William Palmer had feloniously murdered the asssured, from whom he claimed on an assignment, was admissible to prove that he had murdered him. William Palmer had been convicted and hanged for the murder of another person, and had never been tried for the murder in question. Romilly M.R. held that the verdict of the coroner's jury was admissible as prima facie evidence of guilt. There are other cases in which a verdict of a coroner's jury has been admitted to establish the facts on which it was based. In the Victorian (Australian) case of $\mathrm{Wal}$ pole v. Colonial Bank of Australasia, ${ }^{56}$ which involved a finding of suicide in the case of an insurance policy containing a provision that the policy should be void in the event of the suicide of the assured, Molesworth $J$. rejected the standard argument of res inter alios acta and admitted the finding of the coroner's inquisition as prima facie evidence of suicide. However, later cases have reversed this trend. In Bird v. Keep, ${ }^{57}$ Swinfen Eady M.R. said: "In nny opinion the finding of the coroner's jury was not admissible in the present case. It merely amounted to the opinion of the coroner's jury as to the cause of death upon the evidence adduced before them." This introduces the opinion rule as a basis of exclusion; and this, as we shall see, was a principal ground for the rule of exclusion of crimmal convictions in the judgment of Goddard L. J. in Hollington v. Hewthorn. Calmenson v. Merchant's Warehousing Company ${ }^{58}$ is further authority for the exclusion of the findings of a coroner's inquisition. Lord Dunedin pointed out that the parties to the action at law were not necessarily represented at the inquisition and attention might not be drawn to many points which might be of interest in the subsequent action. These cases were followed by McCardie J. in Barnett v. Cohen. ${ }^{59} \mathrm{It}$ is quite clear therefore that the case to which Evans P. referred in his note no longer states the law. ${ }^{.0} \mathrm{It}$ is odd that the course of authority on this point should have moved from admissibility to inadmissibility. But it is submitted that the decisions on this point are not decisive of the issue under consideration here. Much that may be of

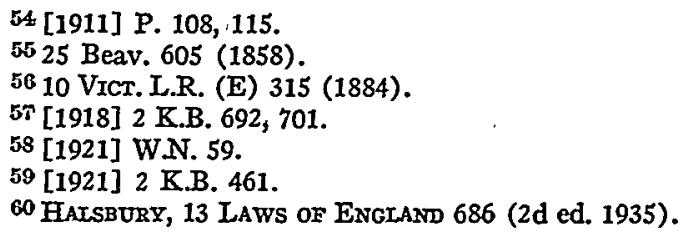


vital importance to the defense of a subsequent criminal action may not have been raised in a coroner's inquisition which, to that extent, provides an imperfect determination of the issue.

Re Crippen was followed by a King's Bench divisional court in Mash v. Darley. ${ }^{61}$ On the hearing of a complaint under the Bastardy Laws Amendment Act 1872, evidence was tendered of the conviction of the alleged father on an imdictment charging him with unlawful carnal knowledge of the complamant. Counsel sought to distinguish $R e$ Crippen, arguing that the rule in that case applied only where a convicted felon sought to establish a claim arising from his own wrong. Apart from this situation it was contended that the principle stated by Bramwell L.J. in Leyman v. Latimer applied. The Court (Ridley, Scrutton and Bailhache JJ.) rejected this argument, and $R e$ Crippen was treated as authority for the proposition that proof of a conviction was presumptive proof of the commission of the crime. Mash v. Darley was affirmed by the Court of Appeal on different grounds, and no reference was made to the point at issue there. ${ }^{22}$

There follow three cases in the Divorce Division. Partington v. Partington and Atkinson ${ }^{63}$ was a husband's divorce action. The co-respondent put in a decree of a former suit in which the husband had himself been found guilty as a co-respondent. Horridge J., after consultation with the President, admitted this evidence. It does not appear to have been argued by counsel for the petitioner that this evidence was inadmissible. In O'Toole v. O'Toole, ${ }^{\text {th }}$ some difficulty was experienced by Hill $\mathrm{J}$. Evidence of the conviction of the respondent for perjury in falsely swearing that he had not had sexual intercourse with a woman was tendered to prove the commission of adultery by him. Hill J. was troubled by a passage in Stephen's Digest of Evidence to the effect that statements in judgments as to facts on which the judgments were based are deemed irrelevant as between strangers or as between a party and a stranger, except in specified cases. The judge decided to admit the evidence on the authority of Partington v. Partington, at the same time confessing his difficulty in reconciling that decision with the passage in Stephen. In Little v. Little, ${ }^{65}$ on a wife's petition for divorce on the ground of adultery, Hill $\mathrm{J}$. admitted evidence of a finding of adultery against the husband in a former divorce suit in which he had been corespondent. In this case the question of admissibility on the grounds with which we are concerned does not appear to have been argued.

Before considering Hollington v. Hewthorn, it should be noted that there are cases im which courts have treated convictions for crime as proving the fact of commission of the crime by the convicted person. Thus, for example, in Cleaver v. Mutual Reserve Fund Association, ${ }^{66}$ which is a leading case on the rule that a wrongdoer cannot take a benefit from his own

61 [1914] 1 K.B. 1.

62 [1914] 3 K.B. 1226.

63 [1925] P. 34.

6442 T.L.R. 245 (1926).

65 [1927] P. 224.

66 [1892] 1 Q.B. 147. 
wrong, the conviction of Mrs. Maybrick for the murder of her husband was treated throughout on the footing that it proved the commission of the murder by her. But as Hall V. C. pointed out in Yates v. Kyffin-Taylor, no argument was addressed to the court on this point, and the courts dealt with the matter on the assumption that Mrs. Maybrick had in fact mur-

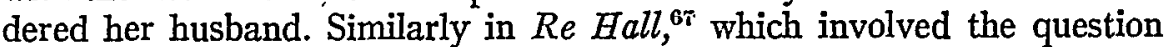
whether the rule in the Cleaver case applied to manslaughter, the case was argued on the footing that the conviction established the fact of the commission of the felony. The latter case is cited by Phipson ${ }^{68}$ as authority for an exception to the general rule of exclusion with which we are concerned, but the most cursory examination of the case shows that it is not an authority on this point.

In Hollington v. Hewthorn, which is the principal modern English decision on this question, damages were claimed in respect of a collision between motor cars. The first defendants, Hewthorn \& $\mathrm{Co}$., were the owners of a car involved in the collision and driven by the second defendant, Poll. Owing to the death of the driver of the plaintiff's car, the plaintiff was unable to adduce any direct evidence of the accident and he tendered as evidence of negligence a conviction of defendant Poll for careless driving under the Road Traffic Act 1930 at the time and place of the collision. The Court of Appeal, upholding Hilbery J. on this point, held that the conviction was inadmissible. Goddard L.J. delivered the judgment of the court. His reasons may be stated in summary form: (1) The modern law of evidence, unlike the earlier law, is concerned with relevance and not primarily with the competence of witnesses. Generally, the relevant evidence is admissible. This evidence is not relevant, but is only the view of another court that it considered the defendant guilty of careless driving on evidence and considerations not known to the civil court. (2) It is res inter alios actathe issues in the criminal and civil proceedings are not identical. (3) It is open to the objection of irrelevance as opinion evidence, as the conviction is only the opinion of the criminal court. (4) It is hearsay. (5) If a conviction is admissible, an acquittal should equally be admitted, and it has never been suggested that an acquittal is evidence. (6) The authorities are against admissibility. Evans P. was not justified in Re Crippen in disregarding authority, especially Castrique v. Imrie and Leyman v. Latimer. It follows that Re Crippen, Partington v. Partington and O'Toole v. O'Toole are contrary to the authorities and ought not to be followed.

This judgment, which contains all the important arguments against the admissibility of criminal convictions, calls for careful consideration. It will be noted that Goddard L.J. was careful to distinguish relevance and competence, and stated as a principle the general admissibility of relevant evidence. He then held in terms that the criminal conviction was not relevant. It is quite clear that Goddard L.J.'s use of relevance here is identical with Stephen's use of the term in his Digest of Evidence. There "relevant"

67 [1914] P. 1.

68 Phipson, Evidence 407. 
is used interchangeably with "admissible." But the almost invariable meaning of relevant im the modern law of evidence is "logically probative." It is submitted that the evidence of the conviction is logically probative evidence for the purposes under consideration. It is difficult otherwise to explain the English Criminal Evidence Act 1865, Section 8, which permits the cross-examination of a witness as to his prior convictions, which may be proved aliunde if he denies them. The object of such cross-examination is to discredit the witness. Clearly if the conviction is not to be regarded as evidence of the commission of the criminal act this would be an absurd and prejudicial rule.$^{70}$ Further, it is submitted that there is strong judicial support, almost contemporary with Hollington $v$. Hewthorn, for the proposition that evidence of this sort is relevant in the logically probative sense. In General Medical Council v. Spackman, ${ }^{71}$ Spackman, a registered medical practitioner, was found guilty of adultery in divorce proceedings. Proceedings were then instituted before the General Medical Council to determine whether his name should be erased from the medical register. Spackman sought to tender fresh evidence to disprove the adultery, but the Council refused to hear it and directed the erasure of his name from the register. Spackman contended that because of the refusal to hear the evidence there had not been a due inquiry under the Medical Act 1858, and that he had suffered a denial of natural justice. Throughout the judicial proceedings it was stressed. that the General Medical Council was not bound by the ordinary rules of evidence, and could adopt such procedure as it deemed appropriate, provided that in so doing it did not violate the rules of natural justice. In the King's Bench Division, ${ }^{72}$ it was held, Singleton J. dissenting, that there had been no violation of natural justice. Singleton J. in his dissent referred to Partington v. Partington where it had been held that the evidence of the finding in the earlier divorce suit was admissible, but certainly not conclusive evidence in the later action. In treating the finding of the divorce court as conclusive, and in refusing to Spackman the right to call evidence in disproof before the Council, Singleton J. held that there had been a denial of natural justice. The decision of the King's Bench divisional court was reversed by the Court of Appeal ${ }^{73}$ and the House of Lords ${ }^{74}$ which unanimously supported the dissenting judgment of Singleton J. below. In the Court of Appeal, it is particularly noteworthy that Goddard L.J. said, " "whether the case before them is disputed or undisputed, there can be no reason why they should not accept, if they see fit, the decree as prima facie evidence that adultery was committed." In the House of Lords, Lord Sinon L.C. stated ${ }^{\text {IB }}$ in very clear terms that evidence of the finding

69 Wright, 21 CaN. B. Rev. 657 (1943).

70 See Goodhart, supra note 50, at 301.

71 [1943] A.C. 627.

T2 [1942] 2 K.B. 261.

73 [1942] 2 K.B. 261, 272 et seq.

74 [1943] A.C. 627.

75 [1942] 2 K.B. 261, 274. Goddard L.J. was a member of the Court of Appeal in this case and in Hollington v. Hewthom.

T6 [1943] A.C. 627,635 . 
of the divorce court was admissible and raised "a strong prima facie case which throws a heavy burden on him who seeks to deny this charge." Lords Atkin and Wright in like terms held that the divorce finding was prima facie evidence.

It is true that Spackman did not contend that the finding of adultery by the divorce court was inadmissible, but only that it was not conclusive. But apart from two judges in the divisional court who held that the earlier finding was conclusive, Singleton J., the Court of Appeal and the House of Lords specifically stated that the evidence was admissible and raised a prima facie case. Now it is true that the General Medical Council is not an ordinary court, is not bound by the ordinary rules of evidence, and that its findings will not be upset if there is no denal of natural justice. But natural justice requires that there must be some probative evidence upon which the Council can act before it deregisters a practitioner. It could hardly be suggested that a finding of the Council which was based on no relevant evidence whatever and which resulted in the deregistration of a medical practitioner would be allowed to stand. It is abundantly clear that every judge in the three courts in the case of Spackman, Goddard L.J. among them, considered that the finding of the divorce court was relevant, that is to say, logically probative evidence on which the General Medical Council might act. If this is right, then in holding in Hollington v. Hewthorn that the finding of the criminal court was irrelevant, Goddard L.J. was not treating "relevant" as meaning "logically probative." But if the Court of Appeal did intend to give relevance this inodern ineaning, then, in company with a learned critic of the decision, "with this conclusion we can only say that we emphatically disagree." 77

The next proposition was that the evidence is res inter alios acta. Now we have seen that this was one of the earliest objections to the admissibility of this type of evidence. The argument runs that the parties are different, and the issues are different in the criminal and in the subsequent civil proceedings. But it is difficult to regard these arguments as strong enough to exclude evidence which on the argunent already advanced is logically probative. The Latin inaxim, as was pointed out in Re Crippen, is res inter alios acta alteri nocere non debet. ${ }^{78}$ In view of the fact that the person against whom it was sought to raise the conviction in the present case had a full opportunity before the criminal tribunal to establish his defense, can it be said in a case in which he is a party to the subsequent civil proceedings that he suffers prejudice in violation of this maxim? And on general principles, in cases in which the convicted person is not a party to the subsequent civil proceedings (e.g., in the case where $A$ brings an action on a bill of exchange against $B$, and it is sought to tender the conviction of $C$ for forgery of the bill), it is submitted that the introduction of the maxim imports alien notions drawn from the law of estoppel into a case in which estoppel is in no sense material. Estoppel operates to conclude an issue;

77 Wright, supra note 69.

78104 L.T. Probate 224, 226 (1911). See text at note 51 supra. 
whereas all that is aimed at by the introduction of the evidence of conviction is prima facie proof.

A point to which brief reference was made in the opinion in Hollington v. Hewthorn $n^{79}$ was that a holding that convictions are admissible for this purpose would lead to the conclusion that "if a conviction of murder is admissible, so must one be of a motoring or licensing offence, and to say that the State has an interest in summary convictions of this sort so as to attribute particular value to thein as evidence, seems to us . . . to be more theoretical than practical." The point is that summary convictions before inferior tribunals may often be thought to be lacking in the probative force which attaches to convictions by superior courts. In the case of motoring offenses, for instance, the relative triviality of the penalties may produce this result. Now this point has some support in other jurisdictions. In the recent New York case of Walther $v$. Newes Syndicate Co. ${ }^{80}$ involving the admissibility of a conviction for dangerous driving as evidence in a subsequent negligence action, the question was raised but not decided whether the evidence might have been admissible had the conviction been for a "crime" as opposed to a traffic infraction. It has been suggested by one commentator that, in respect of minor offenses and traffic infractions and having regard to the considerations referred to above, it would be a misuse of judicial authority to establish as a penalty for these practices the possibility of almost unlimited civil liability. ${ }^{81}$ The point is given some support by the terms of recent South Australian legislation. ${ }^{82}$ This provides for the admissibility of criminal convictions in subsequent proceedings in respect of criminal convictions by the Supreme Court, while verdicts of inferior courts are to be admitted only if it appears to the court that the admission is $m$ the interests of justice. It is submitted that considerations which stem from the possible imperfection of lower court convictions should go to weight and not to admissibility. It is not argued that a conviction should be anything more than prima facie evidence. Further, it may be observed that the exclusion of the evidence of the conviction for the traffic offense in Hollington $v$. Hezothorn resulted in a very real hardship to the plaintiff as it left hin, in effect, without evidence. ${ }^{83}$

The objection that the criminal conviction is only the opinion of the criminal court and is therefore excluded under the opinion evidence rule has support from at least one distinguished authority. ${ }^{94}$ Wigmore sharply disagrees, and states that the considerations which may justify the opinion rule in some cases have no application here. ${ }^{85}$ This objection has also been examined by Dean Wright in a powerful criticisin of Hollington v. Here-

\footnotetext{
79 [1943] K.B. 587, 602 .

80276 App. Div. 169 (1949).

812 SYRACUSE L. REv. 112 (1950). See, also, Note, 25 N.Y.U.L.Q. Rev. 1273-4 (1950).

82 EVIDENCE AMTENDMENT ACT, 1945, \&.34A.

83 The driver of plaintiff's automobile had died after the criminal conviction and before the civil action.

84 Hinton, supra note 14.

855 WIGAYORE, EVIDENCE 687.
} 
thorn. ${ }^{86}$ He points to the fact that the opinion rule has itself been the subject of much criticism, and, what is more important, is subject to very many statutory and common law exceptions. His pungent comment on the application of the opinion rule to this case is very much to the point: "To state that a civilized community is willing to see a man hanged on such a finding of fact but to treat such a finding as a mere opinion in a subsequent case involving a matter of dollars and cents is a reflection on the administration of justice as well as an offence to common sense." 87 The criminal conviction may not always produce such a dramatic result, but it is thought that the exceptions which are allowed to the opmion rule fully justify admissibility of the verdict of criminal courts in subsequent civil proceedings.

The argument based upon the hearsay rule nray be dealt with briefly. The admissibility of the criminal conviction has been characterized by a modern American commentator as "a flagrant violation of the hearsay rule." 88 This ignores the point nuade by Wigmore that evidence of many inquisitions and official reports is already authorized at common law and by statute, and it is difficult to see why the determinations of criminal courts slould be differently treated..$^{89}$

Perhaps the oddest of the objections of the Court of Appeal to admitting the evidence of the conviction was the argument that an acquittal is never admissible. For this reason, it was argued that it follows equally that a conviction should be excluded. A simple answer to this argument appears in the opinion of the New York Court of Appeals in Schindler v. Royal Insurance Co.90

While a judgment of acquittal is only a determination that guilt has not been established beyond a reasonable doubt, although a preponderance of evidence might point thereto, a valid judgment of conviction in a court of competent jurisdiction, with all the safeguards thrown about a person accused of crime which enable him to make his defence, to examine witnesses and to testify in his own behalf, might be held free from collateral attack.

The distinction between a conviction which is a finding that the accused has been proved guilty beyond a reasonable doubt, and an acquittal which is simply a holding that the prosecution has failed to discharge this onus, has been emphasized in many places in this connection. ${ }^{11}$ In Helton $v$. Allen, ${ }^{92}$ the point was considered in the High Court of Australia. Dixon, Evatt and McTiernan JJ., in a joint judgment, referred to the question whether an acquittal might be tendered in subsequent civil proceedings. The learned judges said: ${ }^{83}$

\footnotetext{
86. 21 CAN. B. Rev. 653 (1943).

$87 \mathrm{Id}$. at 658 .

882 SYRACUSE L. REV. 111 (1950); see also Hinton, supra note 14.

895 WIGMORE, EVIDENCE 687.

90258 N.Y. 310 , 179 N.E. 711 (1932).

91 See Eagle Star and British Dominions Ins. Co. v. Heller, 149 Va. 82, 140 S.E. 314 (1927).*

9263 C.I.R. 691 (1940).

23 Id. at 710. Contra: Re Emele [1941] 4 D.I.R. 197.
} 
Nor indeed do we think it [a verdict of acquittal] would be admissible against her as an evidentiary fact .... The distinction between the effect of an acquittal and a conviction ... makes irrelevant the decision of Sir Samuel Evans P. in the Estate of Crippen admitting a conviction of murder in evidence.

The Court of Appeal's professed reliance' on authority in Hollington v. Hewthorn was weakened by a failure to consider Hill $v$. Clifford, which it seems is a clear authority of the Court of Appeal in support of admissibility. Counsel in Hollington v. Hewthorn apparently did not cite Hill v. Clifford to the court, although he did refer ${ }^{94}$ to Harvey v. $R .^{95}$ which was cited as support by the Court of Appeal in Hill v. Clifford. Moreover, the authorities discussed by the Court of Appeal in Hollington v. Hewthorn were not wholly in line with the decision reached, and it was necessary for the court to express formal disapproval of Re Crippen, Partington v. Partington and O'Toole v. O'Toole. The present position is that Hill v. Clifford and Hollington v. Hewthorn both stand as decisions of the same court, and it is submitted that there is no distinction of substance between them. The relevant decisions were cited to the Court of Appeal in the earlier case, so that Hill $v$. Clifford cannot be said to have been decided per incuriam. The result may very well be that in view of the rule and the qualifications on the rule in Young v. Bristol Aeroplane Co. Ltd..$^{96}$ the Court of Appeal (and inferior courts) will be put to an election as between two conflicting decisions.

Finally, there is the argument $a b$ inconvenienti in Hollington v. Hewthorn. The evidence is not admissible "owing mainly to the impossibility of determining what weight should be given to it without retrying the former case." The point is expressed rather more brutally by Hinton. "Privately we doubt the capacity of the jury to evaluate ordinary evidence [in the subsequent civil action] .... [T] he present jury, if it really considers the matter, must either blindly accept the conclusion of the first jury or ignore it because there is no rational alternative." As Wigmore drily observes, this is an odd argument. We allow juries to decide matters of the most momentous import to life and liberty, but then throw aside their work as worthless. ${ }^{99}$ It may be in these cases that there will be some difficulty, whether it be the concern of a judge or a jury in the subsequent civil action, in evaluating the conviction. But all that is contended for is the admissibility of the conviction as evidence, which would permit a party relying on the conviction to put it in as prima facie proof of the facts on which it is based. This would throw on the other party the tactical onus of challenging the correctness of the criminal verdict. It seems altogether absurd to re-

94 [1943] K.B. 587, 590 .

95 [1901] A.C. 601 .

D6 [1944] K.B. 718. See Goodhart, Precedents in the Court of Appeal, 9 CASrB. L.J. 349 (1947).

97 [1943] K.B. 587, 595.

98 Hinton, supra note 14.

99 5 WIGMORE, EYIENCE 687. 
quire an insurance company, resisting an action on a policy on the ground that the claimant was seeking to profit by his own wrong, to prove the allegations de novo, and to deny it the right to rely at all on the conviction of the claimant. Courts are used to weighing evidence. It is obvious that a conviction in a superior court may obtain more credence in subsequent civil proceedings than a conviction in a magistrate's court for some minor traffic offense. It is submitted that considerations of convenience and common sense should lead to the admissibility of the conviction as evidence of the truth of the matters found.

\section{III}

We turn next to the Canadian, South African and Australian treatment of this problein. For these purposes, the various South African jurisdictions may properly be regarded as common law countries, as it is specifically provided that in the absence of statutory provision to the contrary the Southern African law of evidence is English law. ${ }^{100}$

The Canadian cases have not followed a clear line. In Re Noble, ${ }^{101}$ a Saskatchewan court on facts similar to those in Re Crippen admitted evidence of the conviction. In Shaw v. Glen Falls Insurance Co., ${ }^{102}$ in an action on a policy insuring a car against theft, it was held by a Nova Scotia court that a conviction of $X$ by a magistrate for the theft of the car was inadmissible. In a discussion of English authority, Leyman v. Latimer was referred to with approval and $\operatorname{Re} C$ Crippen was distinguished on the ground that there the maxim res inter alios acta could not apply as Crippen's executrix was not "alteruin" within the scope of the maxim. ${ }^{103}$ In the instant case the theft was by a third person and Carroll J. said: "The issue in the case against the Insurance Company was whether Brown had stolen the car. There is no doubt that the conviction before the magistrate could not be used in evidence, in proof of theft before the jury."104 It is clear that the basis of exclusion in this case rested on res inter alios acta. In Re Emele ${ }^{105}$ there was a claim under a will in a Saskatchewan court and the question was whether the claimant was barred by her own wrong. She had been tried for murder and acquitted. The court adopted the view that convictions and acquittals were in pari materia in regard to admissibility. On the authority of Lundy v. Lundy, ${ }^{106} \operatorname{Re}$ Crippen and Re Hall, it was held that a conviction was admissible, and it followed that an acquittal was likewise admissible. Disregarding the unsatisfactory identification of convictions and acquittals, the inportant point is that the court thought that a conviction might be tendered. Two of the authorities cited were of doubtful validity.

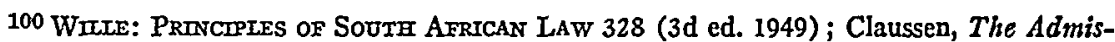
sibility of Evidence of Criminal Convictions in Adultery Cases, 62 So. AFr. L.J. 14 (1945); Surmon v. Surmon, A.D: 47.

101 [1927] I W.W.R. 938.

102 [1938] I D.L.R. 502.

103 See text at note 51 supra.

104 [1938] I D.L.R. 502.

105 Supra note 93.

100. 24 S.C.R. 650 (1895). 
We have seen ${ }^{107}$ that the point was not really argued in $R e H a l l$, and this was also the case in Lundy v. Lundy. But Re Crippen is quite clear.

In La Foncière Compagnie d'Assurance de France v. Perras ${ }^{108}$ the Supreme Court of Canada held the evidence inadmissible. This was a question of liability on an insurance policy and the company argued that it was not liable as the accident occurred while $X$ was committing a criminal offense. It was held that the conviction of $X$ by a magistrate was inadmissible. Rinfret J.'s judgment suggests quite clearly that unless the criminal conviction works an estoppel it is inadmissible.

As long as this cannot constitute res judicata, it is impossible to see what other object appellant could have in view in asking for production of the certificate of judgment in the criminal matter; and on the other hand it is easy to foresee the disadvantages in the production of a document of this nature, for example in a trial by jury, where the mere fact of the conviction could have an influence on the verdict which it should not have..$^{109}$

This is the language of res inter alios acta pitched as high as could be imagined. However, it is not difficult to point out what object other than the creation of an estoppel the appellant could have in view. This case was followed by a British Columbia court in Secretary of State for Canada v. Quon $B o n^{110}$ where it was held that a conviction of a tenant for keeping a disorderly house was not admissible to prove that the tenant had been guilty of a breach of covenant in maintaining or permitting a nuisance on the premises. The judge observed that if $R e$ Crippen was to be followed in Canada, it was for a higher court to decide, and that im any event $R e$ Crippen might be construed as applying only where a criminal or one claiming through him seeks to recover the fruits of crime. It is submitted that to confine the operation of $R e$ Crippen in this way cannot be justified on any ground of principle or policy. If a conviction proves anything in such a case, it is difficult to see in all good sense why it should not establish the same thing in other forms of proceeding.

It will be seen that the Canadian cases have hardened against admissibility, and the Supreme Court decision in the La Fonciere case is quite definite on this point. The reasons are less fully stated than those of the Court of Appeal in Hollington v. Hewthorn and it would seem that a treatment of the question which poses the alternatives of estoppel or exclusion is quite unsatisfactory.

The South African authorities call only for a brief note. There are a number of South African cases in which criminal convictions have been admitted in subsequent divorce proceedings. In Laverence $v$. Lawence $e^{111}$ a divorce petition on the ground of adultery was supported by a tender of the husband's conviction for rape. In Robinson $v$. Robinson ${ }^{112}$ adultery was

\footnotetext{
107 Text at note 67 supra.

108 [1943] 2 D.L.R. 129.

109 Id. at 134-5.

110 [1943] 4 D.L.R. 704.

11115 S.C. 251 (1898).

112 [1906] C.T.R. 16.
} 
again proved by the wife's conviction for bigamy in going through a second form of marriage. In Christie v. Christie ${ }^{113}$ the facts and decision were as in Laverence v. Laverence. Similar decisions were given in a number of cases. In two of these, Kleynhaus v. Kleynhaus ${ }^{114}$ and Dickason v. Dickason, ${ }^{116}$ the courts stated that they were not prepared to hold that such evidence would necessarily be admitted in a defended divorce action. This distinction appears to have no conceivable merit or justification, ${ }^{116}$ and, if followed, would produce one further arbitrary distinction in this unhappy corner of the law. It has been argued that the authority of these cases has been destroyed by Hollington v. Hewthorn. ${ }^{110}$

Finally, the Australian authorities may be noted. In $R$. v. Seer $y^{118}$ an action was brought against a postmistress to recover certain sums or moneys received by the defendant to the use of the plaintiff. The defendant had been acquitted of a charge of fraudulent conversion in respect of moneys of which these were part, and pleaded that the acquittal constituted a defense of res judicata. This argument very properly failed to convince the court. Griffith C.J., in whose judgment Isaacs and Powers JJ. concurred, said: ${ }^{110}$

There are, in my opmion, serious difficulties as to the question whether a verdict in a criminal case ... is admissible under any circumstances as evidence in a civil case, and if so, for what purpose. According to the older authorities it was never admissible. It may be that for some purposes it is admissible. But, if it is, it can only be admitted as res judicata, and only where it appears that the point determined by the verdict is the same point which is in issue in the civil case.

Here again we have the rule of estoppel stated as the test of admissibility. It is odd that there is no reference in this judgment either to $R e$ Crippen, which at the date of this judgment was a relatively recent decision, or to Hill v. Clifford. Neither case conforms to the test propounded by Griffith C.J.

In Davis v. Gell ${ }^{120}$ it was said that special considerations applied in malicious prosecution with respect to the verdict in the antecedent criminal proceedings. Isaacs $\mathrm{J}$. stated that the reason was that the maxim res inter alios acta was not really violated in such a case, as the defendant in the subsequent tort action was in substance the prosecutor in the criminal proceedings. Starke J. agreed, perhaps on the ground stated by Isaacs J., or perhaps, more properly, because of the peculiar and exceptional character of the action for malicious prosecution, and because of considerations of

113 [1922] W.L.D. 109.

114. [1933] O.P.D. 110.

115 [1934] N.P.D. 97.

116 See Claussen, supra note 100 , at 16.

117 See Claussen, supra note 100.

11819 C.L.R. 15 (1914).

110 Id. at $16-17$.

12035 C.L.R. 275 (1924). 
public policy. It is clear from these judgments that the general rule was that of exclusion: per Isaacs J., because of the operation of the rule of res inter alios acta. In Wing On \& Co. Ltd. v. Collector of Customs for New South Wales, ${ }^{121}$ Starke J. said: "Conviction for an offense is not, I think, relevant evidence in a civil proceeding of the matters of fact involved in that conviction." This statement was not supported by an examination of the authorities. Here the judge adopted the test of relevance as the reason for exclusion. This point has been discussed in connection with Hollington v. Hewthorn. ${ }^{122}$ In Helton $v$. Allen, ${ }^{123}$ to which reference has already been inade, ${ }^{124}$ Starke J. referred to Castrique v. Imrie, Cleaver v. Mutual Reserve Fund Life Association, Re Crippen and Re Hall as cases in which convictions were admitted in evidence and acted upon. The judge who had in the Wing $O n$ case held convictions inadmissible on ground of irrelevance now stated that he expressed no settled opinion on the question. ${ }^{125}$ In a joint judgment Dixon, Evatt and McTiernan JJ. simply pointed to the distinction between the effect of an acquittal and a conviction "which inakes irrelevant the decision of Sir Samuel Evans P. in the Estate of Crippen."126

There is a recent Victorian decision, Fendick $v$. Dowmard, ${ }^{127}$ in which the judge expressed the view that a dismissal of a criminal information was at least strong presumptive evidence of innocence. Of the English cases, the judge cited only $R e$ Crippen and Mash v. Darley. It would seem that Hollington v. Hewthorn, in which Re Crippen was disapproved on this point, was not cited to him, and for this reason the authority of this judicial observation is weak. Recent decisions and legislation in South Australia are, however, of particular interest. In $W . v . W .{ }^{123}$ a conviction of a husband for incestuous adultery was admitted in a wife's petition for divorce on the ground of incestuous adultery. The respondent in this case was not represented by counsel. Napier J. observed that $R e$ Crippen was a point of departure from such older cases as Castrique $v$. Imrie where the view had been taken that a conviction was a determination solely between the King and a subject. The judge saw no difficulty in regarding an indictment as a public inquest in which the court determines as issue between the public on one side and the accused on the other. For this reason, the finding of a criminal court was admissible against an accused person in subsequent proceedings, but it would be inadmissible against a stranger, as it would be unjust to bind any person who could not have intervened at any stage in the earlier criminal proceedings. The judge held that in divorce proceedings the evidence tendered was admissible on the authority of Partington v. Partington, Little v. Little and O'Toole v. O'Toole.

\footnotetext{
12160 C.L.R. 97, 100 (1938).

122 See text at note 69 supra.

12363 C.L.R. 691 (1940).

124 See text at note 69 supra.

12563 C.L.R. 691, 702 (1940).

128 Id. at 710 .

127 [1950] VrCT. L. R. 271, 276-7.

128 [1941] S.A.S.R. 144
} 
In this judgment Napier $J$. drew the same distinction as Evans $P$. in Re Crippen. There, in discussing the maxim res inter alios acta, the President distinguished cases in which the convicted person in the criminal charge was either personally or by privy a party to the subsequent civil proceedings, from those in which the convicted person was not a party to the later proceedings. Now, it has been argued that this is an unsatisfactory distinction for the reason that the maxim res inter alios acta ought not to be invoked in these circumstances. It would seem that this gains support from the fact that Napier J. treated the conviction as in the nature of a public inquest. It would be odd to contend that its probative value as a public inquest was in any way affected by consideration of the question whether the accused in the criminal proceedings was a party to the subsequent civil action. If the matter is to be regarded from the standpoint of hardship, it is to be remembered that in allowing a party to civil proceedings to put in the conviction as admissible evidence, the other party is not prevented from tendering any available evidence to show that the conviction was wrong. But there is considerable hardship in requiring a party to prove de novo what has already been the subject of appropriate investigation in a criminal court.

In Bowering v. Bowering, ${ }^{129}$ the facts were very similar. It was sought to tender the conviction of the husband for sodomy in a wife's petition for divorce on that ground. Mayo J. held that this evidence was inadmissible. The judge stated that he would have followed $W . v . W$. but for the fact that in Helton v. Allen and Hollington v. Herethorn it had been held that evidence of convictions for this purpose were inadmissible in civil proceedings. Helton v. Allen, which was a case of acquittal, had nothing to do with the matter, but Hollington v. Herethorn quite clearly supported the decision.

Shortly after the decision in this case, the South Australian legislature enacted the Evidence Amendment Act 1945. This Act provides for the insertion of two new sections, 34a and 34b, in the Evidence Act 1929-1945.

34a. Where a person has been convicted of an offence and the commission of that offence is in issue or relevant to any issue in a civil proceeding, the conviction shall be evidence of the commission of that offence admissible against the person convicted or those who claim through or under him but not otherwise: Provided that a conviction other than upon information in the Supreme Court shall not be admissible unless it appears to the court that the admission is in the interests of justice.

34b. Where in any proceedings in the Supreme Court in its matrimonial causes jurisdiction a person has been found guilty of adultery, the decree or order of the court reciting or based upon that finding shall be admissible in any subsequent proceedings in the Supreme Court in its matrimonial causes jurisdiction as evidence of the adultery as against that person, notwithstanding that the parties to the proceedings in which the finding is tendered are not the same as in the proceedings in which the decree or order was made.

129 [1944] S.A.S.R. 145. 
It has been held in Hartley v. Hartley ${ }^{130}$ that Section $34 \mathrm{a}$ is not limited to convictions by South Australian courts, but authorizes the admission in evidence of convictions of appropriate courts in other jurisdictions.

It appears that Section 34a contains the first general provision for admissibility of criminal convictions in subsequent civil proceedings. Section $34 \mathrm{~b}$ does not deal with evidence of criminal convictions, but it is clearly intended to undo the judicial disapproval of Partington v. Partington by the Court of Appeal in Hollington v. Hewthorn. A case like Bowering v. Bowering or O'Toole v. O'Toole would fall under Section 34a, as the subsequent evidence in divorce proceedings was of criminal convictions. As for Section 34a, it should be noted (1) that civil courts are obliged only to admit criminal convictions in the Supreme Court; convictions in inferior courts are to be admitted only within the discretion of the civil court, when it considers the admission to be in the interests of justice; (2) that it preserves the distinction made by Evans P. in Re Crippen and by Napier J. in $W . v$. $W$., for it is specifically provided that the conviction is admissible against the person convicted or those who clain through him but not otherwise. The first of these limitations deals with the point made by the Court of Appeal in Hollington v. Hervthorn ${ }^{131}$ that on the question of admissibility there is no justification for distinguishing between the verdicts of various courts of criminal jurisdiction and that "if a conviction of murder is admissible, so must one be of a motoring or licensing offence, and to say that the State has an interest in summary convictions of this sort so as to attribute particular value to them as evidence, seems to us, with all respect, to be inore theoretical than practical." It has been suggested ${ }^{132}$ that convictions of all courts should be admissible as prima facie evidence. The character of the court and the nature of the proceedings. would, no doubt, be very important considerations in assessing the weight to be attributed to the evidence. On this point, the South Australian legislation produces a compromise solution; convictions of superior courts are admissible, provided that the commission of the offense is in issue or relevant; while convictions of inferior courts are only admissible if the court is of opinion that the admission is in the interests of justice. With this part of the section, since there is no rigid rule of exclusion based upon the jurisdiction in which the conviction has been obtained, there can be no great quarrel.

So far as the second point is concerned, it is submitted, for the reasons which have already been given, that there is an unfortunate importation of the maxim res inter alios acta into a situation in which the maxim omnia praesumuntur rite esse acta is more properly applicable. It is difficult to see why the probative force of the conviction is stronger if the accused or his privies are parties to the subsequent civil proceedings. If this is not the point, it is subinitted that the danger of prejudice to a third person (who was not involved in the criminal proceedings) does not outweigh the policy

130 [1948] S.A.S.R. 39.

131 [1943] K.B. 587, 602.

${ }^{132}$ See text at note 79 supra et seq. 
considerations in favour of the admissibility of relevant prima facie evidence. It need only be added that the terms of Section 34 show quite clearly that the South Australian legislature wholly rejects the view expressed in Hollington v. Herwthorn that the evidence of the criminal conviction cannot be relevant.

\section{IV}

This survey serves to make the point that there is great uncertainty and difference of opinion on this question in common law jurisdictions outside the United States. The recent trend of English authority is clearly against admissibility, but, for the reasons given, it is thought that Hollington $v$. Hezothorn is not a very satisfactory case. Moreover the line of English authority does not unequivocally support the position taken by the Court of Appeal in that case. In fact, it is at least arguable that there is conflict in the authorities on the same curial level, and that Hollington v. Hewthorn and Hill v. Clifford give conflicting answers to the question. It is open to the highest English appellate tribunal, the House of Lords, to provide a ruling either way. So far as other common law jurisdictions are concerned, the trend in Canada appears to be against admissibility, but the language of the most recent Canadian Supreme Court decision treats the problem as raising issues of estoppel. Whatever case may be made against admissibility, arguments based upon estoppel are the least satisfactory, as no one is seeking to set up an estoppel. The South African cases are concerned with divorce proceedings and there the evidence has been admitted. However, there appears in the later cases a suggestion of a distinction between defended and undefended proceedings which seems altogether irreconcilable with any sound principle. In Australia the earlier opinion in the High Court appears to have been against admissibility on the ground of res inter alios acta, but the latest High Court authorities express no clear opinion on the point. The South Australian authority which held-against admissibility purported to follow Hollington v. Herwthorn, thereby reversing an earlier case and leading to the enactment of general statutory provisions in favour of admissibility.

It is submitted that the inost satisfactory course is to adopt such a rule as is provided by the American Model Code, Rule 521. Evidence of a subsisting judgment adjudging a person guilty of a criminal offense should be admissible as tending to prove the facts recited therein and every fact essential to sustain the judgment. This does not limit admissibility to cases in which the person found guilty or his privies are parties to the subsequent civil action, nor does it draw a distinction between the status of various courts of criminal jurisdiction. But if it should be felt that there is need to balance the probative force of the conviction against any prejudice the admission may cause, it nay be that a practical solution can be found in the provision in the South Australian Act of 1945 that relevant criminal judgments of superior courts must always be admitted; while the courts will have a discretion to decide whether the admission of a conviction by an inferior criminal court is in the interests of justice. On the balance, however, it would seem that a general principle of admissibility, without any such distinction, is to be preferred. 